\title{
Judicial Administrative Cognition, and Refusal to Appoint a Judge - Several Reflections against the Background of the Supreme Administrative Court's Decision of 7 December 2017, Ref. I I OSK 857/17
}

\begin{abstract}
The paper indicates the most important arguments raised by the participants in the dispute concerning the possibility of control by the administrative courts of decisions of the President of the Republic of Poland on the refusal to appoint a judge and an attempt to make a substantive evaluation of them. In my opinion, the refusal to appoint a judge, as well as refusal to accept the judge's position under the amended Act on the Supreme Court (SC) should be strictly exceptional and in principle be justified at the constitutional level, which should be seen as the duty of the President to ensure compliance with the Constitution. Both of these resolutions should contain the motives of the President, which would make this act, with all its arbitrariness, more transparent. This is important not only from the point of view of the person concerned, but this also has an important social dimension. The public has the right to know, not only which candidates, who met the requirements for the appointment as a judge and were recommended by the National Council of the Judiciary of Poland (NCJ), were not appointed by the President, but also what reasons were at the heart of such a decision of the Head of State.
\end{abstract}

Keywords: presidential prerogatives, administrative court, president

Prof. Michał Kowalski - Kozminski University; e-mail, mkowalski@kozminski.edu.pl; ORCID: 0000-0002-8112-0922. 


\section{Introductory remarks}

By the decision of 22 June 2016 issued on the basis of Article 179 of the Constitution of the Republic of Poland ${ }^{2}$, the President of the Republic of Poland refused to appoint three individuals as a district judge, a regional judge and a judge of the court of appeal. They filed complaints in the Voivodship Administrative Court in Warsaw under the Law on Proceedings before Administrative Courts ${ }^{3}$. In the claimants' opinion, the President of the Republic of Poland could not liberally use his prerogative to appoint judges, he was bound by the conditions and procedure of the nomination, as well as he could not evaluate the qualifications of the candidates for the positions of judges and make opinions on their candidacies. Moreover, the claimants raised that the application of the National Council of the Judiciary was binding in the situation in which the candidates for the positions of judges met the statutory requirements and were successful in the selection procedure and were introduced by the NCJ in the appointment application. It was raised that there had been no constitutional and legal impediments to the nominations of these persons, and the lack of justification for the refusal to nominate them makes it more difficult to verify its legality and the proper use of the prerogative by the President. This also deprives the candidates of the possibility of knowing the motives for the refusal. In this light, it was argued that the decision issued by the President is a public administrative act which confirms the powers resulting from legal regulations and therefore, is subject to judicial-administrative control pursuant to Article $3 \S 2$ point 4 of the L.P.A.C.

In response to the complaint, the President of the Republic of Poland filed for its rejection due to the lack of the administrative court's competence in this matter, and in case it was entertained, for dismissing it as unfounded. The Ombudsman and the Helsinki Foundation for Human Rights, both supporting the complaint of the candidates for judges, applied for participation in the proceedings. The

2 On the basis of Article 179 of the Constitution of the Republic of Poland of 2 April 1997 (Dz. U. Nr 78, poz. 483 ze zm./Journal of Laws No. 78, item 483 as amended - hereinafter referred to as the Constitution of the Republic of Poland), judges are appointed by the President of the Republic of Poland, upon request of the National Council of the Judiciary, for an indefinite period of time.

3 Act of 30 August 2002 - Law on Proceedings before Administrative Courts (i.e. Dz. U. z 2018 r. poz. 1302/Journal of Laws of 2018 item 1302 - hereinafter referred to as the L.P.A.C.). 
complaint was rejected by the Voivodship Administrative Court (VAC) in Warsaw ${ }^{4}$, which referred i.a. to the content of the resolution of the Supreme Administrative Court (SAC) of 9 November 1998, in which it was ruled that within the scope in which the President of the Republic of Poland acts as Head of the Polish State, by symbolising its majesty and sovereignty, the fully discretionary power of the State exceeds the area of activity of the public administration and it does not constitute the performance of public administration, and thus, it cannot be controlled by the administrative court. ${ }^{5}$ The VAC also referred to a series of rulings of the SAC from 2012-2013, in which a line of judgements was shaped. This line stated the lack of judicial administrative cognition in cases concerning actions against presidential decisions regarding refusal to appoint a judge. ${ }^{6}$

The essence of the judgement of the first instance court came down to an assumption that a decision to refuse to appoint a judge does not constitute an application of the law in the strict sense and it is not the performance of the public administration. The President does not have an administrative function in this regard. The decision to refuse to nominate a judge is the realisation of the President's autonomic and discretionary powers. Just like appointing a judge is an independent and discretionary activity of the President, as the result of which the Head of State confers on a specific person the power to act in a judicial capacity, the refusal to appoint a judge constitutes an element of the discretionary power of the President. By order of 7 December 2017, the SAC dismissed all complaints in cassation filed in this case. 7

This paper does not aspire to be a complex discussion of the legal nature of the presidential act concerning judicial nominations as well as refusal to appoint a judge. This issue was thoroughly discussed in the doctrine of constitutional law and in the case law of the Constitutional Tribunal and administrative courts, therefore, I will attempt to indicate the most essential arguments raised by the participants of this dispute below and formulate my own evaluation of the issue against this background. At the early stage, I am most inclined towards a concept,

4 Postanowienie WSA w Warszawie z dnia 29 grudnia 2016 r., sygn. akt II SA/Wa 1652/16 (Decision of the VAC in Warsaw of 29 December 2016, Ref. No. II SA/Wa 1652/16), www.orzeczenia.nsa.gov.pl.

5 Uchwała Składu Siedmiu Sędziów NSA z dnia 9 listopada 1998 r., sygn. akt OPS 4/98, ONSA 1999 r., nr 1, poz. 6 (Resolution of the Panel of Seven Judges of the SAC of 9 November 1998, Ref. No. OPS 4/98, Ruling of the SAC of 1999, No. 1, item 6).

6 Orders of the SAC: of 30 March 2013, Ref. No. I OSK 3129/12; of 16 October 2012, Ref. No. I OSK 1785/12 and I OSK 1786/12; of 17 October 2012, Ref. No. I OSK 1887/12 and I OSK 1889/12; of 9 October 2012, Ref. No. I OSK 1883/12 - orzeczenia.nsa.gov.pl.

7 Postanowienie NSA z dnia 7 grudnia 2017 r., sygn. akt I OSK 857/17 (Decision of the SAC of 7 December 2017, Ref. No. I OSK 857/17), www.orzeczenia.nsa.gov.pl. 
according to which in a democratic state of law, it should be guaranteed that powerful judgements of a public administration body, also including the constitutional body of the executive power, are subject to judicial control, especially when they concern the area of rights and freedoms included in the second chapter of the Constitution of the Republic of Poland, such as the principle of equal access to public service. The essence of this provision is to ensure equal chances in applying for positions in public offices, with no guarantee of being appointed to a given post. However, it is necessary to indicate clear criteria for the selection of candidates and establish proper procedural guarantees, also by way of court proceedings, allowing for the verification of judgements made in this regard. ${ }^{8}$ Any potential judicial administrative control of acts of this kind would involve the necessity of justifying judgements which state a refusal in terms of a judicial nomination. In a situation when it is unknown what conditions were at the heart of such a refusal, there will be no unified rules because they remained subject to the discretionary power of the Head of State. ${ }^{9}$

\section{The legal nature of the presidential prerogative on the appointment of judges}

In this area, there is a range of frequently radical opinions. ${ }^{10}$ On the one hand, there are views in the light of which the Constitution grants the President complete freedom in terms of appointing a judge and refusing to appoint one. Actions undertaken in this regard are performed completely on his account and are only subject to liability on general terms. ${ }^{11}$ They indicate that the Constitution does not impose an obligation on him to justify his decision, and the conditions of the judgement itself are not related to the statutory norm providing for the procedure of appointing a judge. This kind of view is closest to the standpoint of the Head of State presented in the case which inspired this paper, and at the same time, it is an element of the constitutional practice in recent years. ${ }^{12}$

8 Wyrok TK 29 listopada 2007 r., sygn. akt SK 43/06 (Judgement of the CT of 29 November 2007, Ref. No. SK 43/06), www.trybunal.gov.pl.

9 A. Szmyt, Wątpliwości wokót reform wymiaru sprawiedliwości, in: Ratio est anima legis. Księga Jubileuszowa ku czci Profesora Janusza Trzcińskiego, Warszawa 2007, p. 489.

10 T. Kuczyński, Z problematyki postępowania w sprawie powołania sędziego sądu administracyjnego, in: W stużbie dobru wspólnemu. Księga jubileuszowa dedykowana Profesorowi Januszowi Trzcińskiemu, eds. R. Balicki, M. Masternak-Kubiak, Warszawa 2012, p. 448.

11 P. Sarnecki, nota 11 Komentarza do art. 144 Konstytucji RP, Vol. IV, Warszawa 2005.

12 B. Banaszak, Konstytucja Rzeczypospolitej Polskiej. Komentarz, Warszawa 2009, p. 795. 
Other doctrinal views do not modify this standpoint much, either. They state that the President is under no legal obligation to give a favourable response to the NCJ's application. Besides, the essence of applying itself comes down to a double way of settling the case. In Article 179 of the Constitution, an application is discussed, which should be associated with its non-binding nature, even in a situation when it is a necessary element of the proceeding in the case. The role of the President of the Republic of Poland should not be reduced to the purely ceremonial confirmation of the positive closure of the procedure conducted before the NCJ. This kind of standpoint, however, sometimes entails a significant objection, according to which a refusal to give a favourable response to the application should be preceded by submitting objections by the President's representative who sits on the Council. ${ }^{13}$ Therefore, in general, the prevalent opinion is that attempts to attribute the role of a notary who blindly approves the NCJ's application to the President lead to ignoring the constitutional competence of this body and as a matter of fact giving a purely formal-bound nature to the personal prerogative. ${ }^{14}$

One should not ignore arguments in favour of the lack of a legal possibility for the President of the Republic of Poland to make use of the refusal to appoint a candidate indicated in the NCJ's application. Such standpoints, however, are most frequently formulated with reference to general systemic rules which should shape proper relations between the judiciary and the Head of State, which is worth emphasising, under the conditions of the appropriate realisation of the concept of the state of law. An opinion that is convincing in this respect takes into account the systemic interpretation of the Basic Law, in the light of which the presidential competence in appointing judges, which is discussed in Article 179 of the Constitution, was placed among norms concerning the guarantee of the stability of the office of a judge, which allows for associating it rationally and more closely with the guarantees of the third power than with the powers of the President which derive from the times of absolute monarchy where a monarch (king) was a sovereign and exercised all types of power. It is noted within this concept that the adoption of the model of binding the President with the NCJ's application for the appointment of a given person as a judge is supported by the circumstance that the President's power resulting from Article 179 of the Constitution should be interpreted, having regard to a wider range of constitutional values, particularly such as the independence and separateness of courts from other powers (Article 173 of the Constitution) and the independence of judges (Article 178 section 1), the

\footnotetext{
13 L. Garlicki, Komentarz do art. 179 Konstytucji RP, Vol. IV, Warszawa 2005, p. 5.

14 W. Sokolewicz, Konstytucyjna regulacja władzy sadowniczej, in: Konstytucja, ustrój, system finansowy państwa. Księga pamiątkowa ku czci prof. Natalii Gail, Warszawa 1999, p. 174.
} 
content of which constitutes an integral element of the right to court ${ }^{15}$. The President's obligation is to safeguard compliance with the Constitution and act as an arbiter in current political disputes, which should make him a supporter of the judiciary, who is above political divisions. In my opinion, respecting this argument would, however, require compliance with the high standards of the state of law and the legal culture. This would come down to a refusal to appoint a judge to the office due to important constitutional impediments, and would require giving clear motives of the Head of State. ${ }^{16}$

In the light of another standpoint, the President of the Republic of Poland, pursuant to Article 126 section 3 of the Constitution of the Republic of Poland, performs his tasks within the scope and on terms specified in the Constitution and acts, and he is also bound by the obligation to act according to and within the limits of the law, therefore he is bound by the principle of legalism which results from Article 7 of the Basic Law. In this light, legal regulations do not give the Head of State the right to verify applications of the NCJ, and thus, they do not give the Head of State the right to question it. This view assumes that a special department empowered to verify the personal file of a candidate for a judge again does not work in the Chancellery of the President. According to this opinion, the President does not have the right to question an application of the NCJ and is obligated to appoint a candidate presented by the Council. ${ }^{17}$ Within the framework of this model which I call bound, it is also assumed that the President cannot refuse to appoint a judge and is obligated to co-operate with the NCJ in this regard. The norms provided for in Article 179 and Article 144 section 3 point 17 of the Constitution cannot be the basis for the issuance of a decision to refuse to appoint a judge by the President of the Republic of Poland. The literal wording of the norm provided for in Article 179 of the Constitution of the Republic of Poland, according to which judges are appointed by the President of the Republic of Poland, upon the NCJ's request, for an indefinite period of time, is primarily indicated in this regard. The competence independence of the NCJ as well as protection of the independence of the judiciary are also pointed out. ${ }^{18}$

15 M. Szwast, Prawo do odpowiedniego ukształtowania ustroju i pozycji organów wymiaru sprawiedliwości, doctoral dissertation defended at the Faculty of Law and Administration of the University of Warsaw in 2017, non-published, p. $261 \mathrm{ff}$.

16 J. Ciapała, Charakter kompetencji Prezydenta RP. Uwagi w kontekście kompetencji w zakresie powotywania sędziów, „Przegląd Sejmowy” 2008, No. 4(87), pp. 40-41.

17 R. Piotrowski, Sędziowie a władza wykonawcza. Wybrane problemy konstytucyjne, "Studia Iuridica” 2008, Vol. XLVIII, p. 212.

18 M Ziółkowski, Prerogatywa Prezydenta RP do powolywania sędziów (uwagi o art. 144 ust. 3 pkt 17 i art. 179 Konstytucji), "Przegląd Sejmowy” 2013, No. 1, p. 65. 
In my opinion, however, it is difficult to share such a radical standpoint. It does not include the President's obligation to safeguard compliance with the Constitution and reduces his role to the blind - positive approval of the NCJ's applications. The flaw of this stance also manifests itself in depriving the nomination procedure of a so-called safety valve that in exceptional situtions would allow - which is worth emphasising - the President to question some candidacies when he has some objective information on constitutional impediments for a given person to hold the office.

In the literature, there are also attempts to formulate opinions which are, as a matter of fact, an expression of searching for consensus between reducing the function of the President to purely ceremonial powers in the procedure of appointing judges and finding sovereign powers in this role, which result from the competence nature of prerogatives..$^{19}$ An expression of such efforts is, among other things, a stance, according to which the President could evaluate an application of the NCJ negatively only when this is supported by extraordinary circumstances which I personally associate with the obligation to safeguard compliance with the Basic Law. Then he could include them in written objections and return the promotion files to the NCJ, for reconsideration. This kind of solution is provided for in the Act on the $\mathrm{NCJ}^{20}$, which indicates in Article 45 section 2 and 3 that in the case of the revelation of new circumstances concerning the person indicated in an application for appointment as a judge or an assessor, presented to the President of the Republic of Poland, the President may also apply for reconsideration. The reconsideration or a refusal of it is decided by the Council by way of a resolution. It is assumed in the case law of the Supreme Court (SC) that the new circumstances discussed in that norm are both the ones which existed during the previous review of the case, but were not known to either the Council, or the participants of the proceedings, and the ones created after the closure of the proceedings and related to the essence of the case and likely to affect the decision on the said case. ${ }^{21}$ In the light of this norm, it is obvious that the President is empowered to make a substantive evaluation of the nomination application. However, in accordance with the views presented in the literature, non-consideration of the President's objections and re-submitting an application for the appointment of a judge to him would be

19 W. Brzozowski, Niezależność konstytucyjnego organu państwa i jej ochrona, Warszawa 2016, pp. 131-132.

20 Act of 12 May 2011 on the National Council of the Judiciary (tekst jedn. Dz.U. z 2019 r. poz. 84/ consolidated text Journal of Laws of 2019 item 84 - hereinafter referred to as the Act on the NCJ).

21 Wyrok SN z dnia 9 sierpnia 2012 r., sygn. akt III KRS 18/12 (Order of the SC of 9 August 2012, Ref. No. III KRS 18/12), www.legalis.pl. 
mandatory for the Head of State in such a situation. ${ }^{22}$ It is also difficult to agree with the latter statement because in my opinion, the President who was granted the power to appoint judges has the right to evaluate facts or circumstances which constitute impediments for the issuance of a positive nomination act differently. In such a situation, however, they should be manifested in the written motives for the decision.

An opinion on this matter was also stated by the Constitutional Tribunal, though, for formal reasons, that statement had a limited substantive scope. The Tribunal, by reviewing the application of the First President of the SC for the decision on the competence dispute between the President of the Republic of Poland and the $\mathrm{NCJ}$ regarding the competence in giving opinions on candidates for judges discontinued the proceedings due to the inadmissibility of granting judgement. The CT indicated, however, that the President may not perform activities which constitute competence to give opinions on candidates for judges, granted to the Council. It also indicated that "in the President's case, his act takes the form of a decision concerning the use (or non-use) of the competence to appoint a judge. The circumstance that in light of Article 144 section 3 point 17 of the Constitution the President's competence specified in Article 179 of the Constitution is treated as the personal power (prerogative) of the President (and at the same time, this is the area of his sole competence and responsibility), and that the President is the supreme representative of the Republic of Poland (Article 126 section 1 of the Constitution), is not without significance for the way of the President's functioning in this regard. Moreover, the lack of specifying the characteristics of the official judicial appointment act remains an essential circumstance [...], and the constitutional form of the decision, published in Monitor Polski, makes the external form of the President's official act not cover the justification of the personal decision made." 2324

The standpoint in the judgement of the CT may be subject to various interpretations. Nevertheless, despite the formal nature of the judgement, in my opinion, it indicated the President's decision concerning the use or non-use of the competence to appoint a judge, which - as it seems - breaks doubts as to the purely ceremonial (bound) nature of this act, as well as it clearly indicated that the form of the act does not cover the justification of a personal decision. Therefore, it seems that also in the Tribunal's opinion, the decisiveness of the President of the Republic of Poland

22 T. Ereciński, J. Gudowski, J. Iwulski, Prawo o ustroju sądów powszechnych, Ustawa o Krajowej Radzie Sądownictwa. Komentarz, ed. J. Gudowski, Warszawa 2010, p. 187.

23 Postanowienie TK z dnia 23 czerwca 2008 r., sygn. akt Kpt 1/08 (Decision of the CT of 23 June 2008, Ref. No. Kpt 1/08), www.trybunal.gov.pl.

24 Own translation [translator's note]. 
was not entirely excluded in this respect. ${ }^{25}$ The proceedings caused by the constitutional complaint about Article $55 \S 1$ of the Act - Law on the System of Common Courts $^{26}$, understood in such a way that it allows for a possibility of the non-appointment of a judge by the President despite the NCJ's application, particularly on the basis of unspecified criteria and without any justification. This is because the Tribunal concluded that the allegations of the claimants concerned the constitutional mechanism, and the legal action available in that case had not been exhausted. ${ }^{27}$ The substantive decision was issued on the basis of circumscribing by the L.S.C.C. of a month as a deadline for the President of the Republic of Poland to appoint judges ${ }^{28}$. This law was considered incompatible with Article 179 and Article 2 of the Constitution of the Republic of Poland. The Tribunal confirmed in it that, among other things, the competence regarding the appointment of judges remains in the area of the sole competence and responsibility of the President, though this does not mean that he may act arbitrarily because he is bound by the principles and values expressed in the Constitution ${ }^{29}$.

The entities questioning the opinion in the decision of the VAC in Warsaw, which rejected the complaint about the act of the President of the Republic of Poland, formulated a standpoint in this respect which reached definitely further than most of the above-mentioned doctrinal and case-law views. They argued that the persons aspiring for the office of a judge had had the subjective right in this regard, according to the NCJ's application, whereas the President of the Republic of Poland had had no reason to issue a decision stating the refusal to nominate a judge. He was not competent to evaluate the qualifications of the candidates for the positions of judges, give opinions on and review their candidacies - this is the competence of other entities and bodies, whereas the decision about using the prerogative should not be made liberally.

However, the SAC did not share these arguments, pointing out that the President of the Republic of Poland is not a body of the public administration in the sense of the provisions of general administrative proceedings. The Constitution

25 See M. Ziółkowski, Prerogatywa Prezydenta RP..., p. 61.

26 Act of 27 July 2001 - Law on the System of Common Courts (i.e. Dz. U. z 2019 r. poz. 52 ze zm. / Journal of Laws of 2019 item 52 as amended - hereinafter referred to as the L.S.C.C.).

27 Postanowienie TK z dnia 19 czerwca 2012 r., sygn. akt SK 37/08 (Decision of the CT of 19 June 2012, Ref. No. SK 37/08), www.trybunal.gov.pl.

28 According to incompatible Article $55 \S 1$ of the L.S.C.C., the judges of common courts are appointed by the President of the Republic of Poland, upon the request of the National Council of the Judiciary, in a month after the day of sending the request.

29 Wyrok TK z dnia 5 czerwca 2012 r., sygn. akt K 18/09 (Order of the CT of 5 June 2012, Ref. No. K 18/09), www.trybunal.gov.pl and prawo.sejm.gov.pl; with a dissenting opinion by P. Tuleja. 
admittedly counts him among the authorities of the executive power, but not among the structure of the administration. ${ }^{30}$ The concept of the executive power is broader than the concept of the public administration, and it also includes pursuing the country's policy, giving fundamental directions of action, as well as controlling and supervising competence. The competence in appointing a judge as well as in refusing to appoint one is a special prerogative of the President of the Republic of Poland as the Head of State. This is an independent and discretionary activity which is not subject to the control of the administrative court ${ }^{31}$.

The court of cassation also made a negative reference to the argument that the President of the Republic of Poland acts as the body of the public administration in other matters, e.g. those regarding access to public information. It indicated that entities obligated to share public information are not identical to the bodies of the public administration. Cases regarding access to public information concern the realisation of a citizen's right resulting from Article 61 of the Constitution of the Republic of Poland ${ }^{32}$ and not from the systemic decisions of the President. The President as a body does not use his prerogatives, however, during proceedings concerning access to public information. In my opinion, however, refusal to nominate a judge also concerns a citizen's subjective right discussed in Article 60 of the Constitution, in the light of which Polish citizens enjoying full public rights have the right to access to public service on equal terms. In this sense, the act of the president does not only constitute a systemic decision of the Head of State, but it decides on the public - constitutionally appointed - subjective right, which, however, occurs by way of using the power that is a presidential prerogative, and this, in turn, significantly differentiates this case from the ones regarding access to public information. ${ }^{33}$

Additionally, there is not any legal-administrative relationship between the President and the person whom the judicial appointment application presented

30 Z. Niewiadomski, Pojęcie administracji publicznej, in: Instytucje prawa administracyjnego, eds. R. Hauser, Z. Niewiadomski, A. Wróbel, Vol. 1, p. 3 ff, C.H. Beck, Warszawa 2015.

31 Postanowienie NSA z dnia 16 października 2012 r., sygn. akt I OSK 1887/12 (Decision of the SAC of 16 October 2012, Ref. No. I OSK 1887/12, www.orzeczenia.nsa.gov.pl.

32 Pursuant to Article 61 section 1 of the Constitution of the Republic of Poland, a citizen has the right to access information about the activity of the bodies of the public authorities or of persons carrying out public functions. This right also covers access to information about the activity of business and professional self-government authorities, as well as other persons and organisational units in the scope in which they carry out the mission of public authority and manage communal assets or property of the State Treasury.

33 For more information, see: M. Kowalski, Nadużycie prawa do informacji publicznej, ZNSA 2016, Vol. 2(65), p. 50. 
by the NCJ concerns. ${ }^{34}$ There also is not any relationship of this kind between the NCJ and the President of the Republic of Poland. Acts issued by the Council (on presenting an application for appointing a judge) and by the President (decision about appointing a judge) are the execution of different competences of both constitutional bodies. Therefore, the President is not bound by the application of the National Council of the Judiciary. Among the prerogatives provided for pursuant to Article 144 section 3 of the Constitution, a range of creative powers used in reference to forming the composition of the most important judiciary authorities, also including the exclusive competence to appoint judges. The act of the President, preceded by actions undertaken in order to select a candidate by the NCJ, does not mean that administrative-legal features may be attributed to the President's activity. The fact that explanatory actions are undertaken in the Chancellery of the President of the Republic of Poland also does not mean that these are actions from the area of administrative proceedings, undertaken in order to settle an administrative case. ${ }^{35}$

Seeking to formulate a general opinion in this regard, I assume that the President of the Republic of Poland cannot take the NCJ's application concerning a judicial nomination into account. In such a situation, pursuant to Article 45 of the Act on the NCJ, he files an application for the Council to reconsider the case, at the same time, providing what circumstances - in his opinion - constitute an impediment for the candidate's judicial nomination. In a situation of the NCJ's re-applying for nomination for the same person, the President, however, has the right to his own evaluation of the circumstances of the case, though in the case of a refusal of the nomination, it is necessary, due to the principles of the state of law, providing the written motives for the decision. Adopting a reversed solution and assuming that the President is necessarily bound by the NCJ's request would lead to reducing the role of the Head of State to undertaking only actions of a ceremonial nature, which is not in keeping with his systemic position in the Polish constitutional system ${ }^{36}$.

A similar solution became applicable within the procedure provided for in the Act on the Supreme Court ${ }^{37}$. In accordance with the norm provided for in it, the

34 R. Hauser, Stosunek administracyjnoprawny, in: Instytucje prawa administracyjnego, eds. R. Hauser, Z. Niewiadomski, A. Wróbel, op. cit., p. 194 ff.

35 M. Kowalski, Terminy w postępowaniu administracyjnymi i sądowoadministracyjnym, Wrocław 2013, p. $19 \mathrm{ff}$.

36 K. Weitz, Komentarz do art. 179 Konstytucji RP, in: Konstytucja RP, Vol. II, eds. M. Safjan, L. Bosek, Warszawa 2016, p. 1045 and references.

37 Act of 8 December 2017 on the Supreme Court (Dz. U. z 2018 r. poz. 5 ze zm. / Journal of Laws of 2018 item 5 as amended - hereinafter referred to as the Act on the SC). 
President of the Republic of Poland, prior to agreeing to further holding of the office by the judge of the SC or the SAC, consults the NCJ. The Council submits its opinion to the President of the Republic of Poland within 30 days of the President's application for that opinion. In the case of non-submission of the opinion within this deadline, it is assumed that the Council gave a positive opinion. Making the opinion, the NCJ considers the interest of the system of justice or an important social interest, especially the rational use of judicial staff or the needs resulting from the burdening of individual chambers with tasks. In this case, the NCJ's opinion is also not binding. According to properly applied Article 39 of the Act on the SC, the date of the expiry or termination of the service of the judge of the SC and the SAC is affirmed by the President of the Republic of Poland ${ }^{38}$. The President's stance when it comes to this issue is the same as in the case of a refusal to appoint or promote a judge to a higher position, so the decision of the President of the Republic of Poland about agreeing or disagreeing to further holding of the office by a judge does not require the countersignature of the Prime Minister because it is within the prerogative that involves the appointment of judges. In the President's opinion, the decision, for the same reasons, does not require any justification. ${ }^{39}$

In my opinion, a refusal to appoint a judge, as well as disagreement to further holding of the judicial office should be exceptional and basically be justified constitutionally. A justification including the motives for refusing to appoint a judge or the lack of agreement to making a further decision is essential not only from the point of view of person involved, but it also has a social dimension. Society has the right to know not only which candidates, meeting the requirements for the position of a judge and recommended by the NCJ, were not appointed by the President, but also what reason were the basis of such a decision of the Head of State. Additionally, a decision without a justification has an influence on such values as personal dignity, veneration and reputation. The President's decision without motives may be, and in reality frequently is, associated with the occurence of some deficiencies in the personal or professional life of a candidate for a judge, which may in a sense translate into the social and professional stigmatisation of such

38 For a negative opinion on the reform of the NCJ, see: L. Garlicki, Niezależność sądownictwa - powotywanie sędziów - nadrzędność konstytucji (kilka uwag nad ewolucją orzecznictwa Sądu Najwyższego w Indiach), in: Aktualne problemy konstytucji. Księga jubileuszowa z okazji 40-lecia pracy naukowej Profesora Bogustawa Banaszaka, eds. H. Babiuch, P. Kapusta, J. Michalska, Legnica 2017, p. 139. See also: A. Łabno, Krajowa Rada Sądownictwa. Pozycja ustrojowa i możliwości reformy. Wybrane zagadnienia, in: Aktualne problemy konstytucji. Księga jubileuszowa z..., p. 438.

39 Komunikat w sprawie oświadczeń sędziów o woli dalszego zajmowania stanowiska w Sądzie Najwyższym i Naczelnym Sądzie Administracyjnym z dnia 11 września 2018 r. (Communication of 11 September 2018 on the Judges' Statements of Intent to Continue to Hold the Office in the Supreme Court and the Supreme Administrative Court), www.prezydent.pl. 
a person. ${ }^{40}$ In the light of the current constitutional norm, it admittedly seems that the President is under no obligation to justify the acts refusing to appoint a judge and the the act of refusal to prolong the possibility for judges to adjudicate, but a change of the constitutional custom in this respect would certainly be well-received both by the legal environment and the society, and it could constitute an expression of good will and constitutional practice.

In my opinion, the target solution in this regard should be a concept which assumes a possibility of the President's refusal to appoint a judge, but in such a situation he should give clear motives for his decision, and this itself should be subject to the administrative court's control. It is worth referring to one of the orders of the Supreme Administrative Court in Brno ${ }^{41}$ in this context. The order regarded judicial administrative cognition in reference to the control of the legality of the acts of the President of the Czech Republic, concerning the refusal to appoint a judge. The case concerned a claimant who was a Doctor of Law, worked as an academic, and then passed judicial examination with an excellent result, and was presented in an application submitted by the government of the Czech Republic to the President for judicial appointment. On 15 March 2005, the claimant received a letter from the Minister of Justice of the Czech Republic in which he was informed that the President had refused to consider the request for a judicial nomination due to the candidate's age. The letter became the object of a complaint filed in the Magistrates' Court in Prague ${ }^{42}$, which, however, rejected it, pointing out that the act of the President of the Czech Republic, regarding the appointment of a given person as a judge, or the refusal of such a nomination, does not constitute a decision about the public subjective rights of the addressee of that decision. The proceeding, during which candidates for judges are selected and nomination requests are presented to the President of the Czech Republic, was not constructed on the basis of deciding on the public subjective right, but on the basis of selecting specified candidacies. For this reason, the Czech first instance administrative court considered itself incompetent to control the legality of such activities. It was pointed out in the justification that no act with a legislative force would give the claimant the right to demand to be appointed as a judge, and if on the grounds of the case

$40 \quad$ T. Kuczyński, Z problematyki postępowania..., p. 452.

41 Wyrok Nejuyšši Správni Soud w Brnie z dnia 27 kwietnia 2006 r., sygn. akt 4 Aps 3/2005 (Order of the Nejuyšši Správni Soud in Brno of 27 April 2006, Ref. No. 4 Aps 3/2005).

42 A hybrid (mixed) model applies in the Czech Republic, in which administrative cases in the first instance are reviewed by common courts - regional courts (Krajské Soudy) and the Magistrates' Court in Prague (Městský soud v Praze), which are judicially supervised in the framework of the reviewed complaints in cassation (kasační stižnost) by a specialised administrative court - the Nejoyšši Správni Soud in Brno. 
reviewed an entitlement resulting from both the substantive law and procedural law could not be derived, then that case was not within the administrative court's field of competence. ${ }^{43}$

The claimant filed a complaint in cassation (kasační stižnost) about this judgement in the Supreme Administrative Court in Brno which lifted the decision of the Magistrates' Court in Prague and referred the case to be reconsidered. At the beginning, the Czech SAC indicated that the legal dispute on the grounds of the case reviewed concerned not the way of handling the application for the appointment of a judge, but whether the case belonged to judicial administrative cognition. It was pointed out further in the justification that, among other things, the President's decision, within which he executes his powers to appoint a judge, corresponded to the essence and form of administrative activities. In this case, the President acts as a public administration body, and this kind of decisions as well as further actions undertaken during the execution of his power regarding the appointment of judges in a democratic legal state must mandatorily be given adequate legal protection.

Apart from the above, it was indicated that administrative courts cannot control the President's action within the procedure of judicial nominations as such. They may, however, evaluate the fulfilment of statutory conditions necessary for holding the function of a judge. In the Court's opinion, this is because the function of the administrative judiciary must not be waived, which, in connection with the protection of the legality of the decisions of the administrative bodies, seeks to fully shape the executive power (which the President is a part of) in accordance with the current principles of a state of law, and that is why the subjective case must be decided on appropriately. In conclusion, it was raised that in a situation when the right to hold the President liable is not in the field of the judicial-administrative competence, but the control of his acts is, the order of the administrative court may mean only a moral appeal for him to be governed by juridical considerations in his function.

In another order ${ }^{44}$, the Nejoyšši Správni Soud in Brno stated that the President's competence regarding the appointment of judges must fulfil the requirements for

43 J. Sułkowski, Dokumenty - wyrok Najwyższego Sądu Administracyjnego w Brnie z dnia 27 kwietnia 2006 r., sygn. akt 4 Aps 3/2005 dotyczący kognicji sądowoadministracyjnej odnośnie do kontroli legalności aktów Prezydenta Republiki Czeskiej w przedmiocie odmowy powołania na stanowisko sędziowskie, Przegląd Sejmowy, No. 4 from 2008 r., p. 304 ff. See also: J. Sułkowski, Uprawnienia Prezydenta RP do powotywania sędziów, „Przegląd Sejmowy” 2008, No. 42008, p. 46 ff.

44 Wyrok Najwyższego Sądu Administracyjnego w Brnie z dnia 21 maja 2008 r., sygn. akt 4 Ans 9/2007 r. (publ. pod nr Dz.U.Cz z 2008 r. NSS) / Order of the Supreme Administrative Court in Brno of 21 May 2008, Ref. No. 4 Ans 9/2007 (publ. Under No. Journal of Laws of the Czech Republic of 2008 NSS). 
the public administration bodies. They include in particular the consideration of statutory conditions provided for the office of a judge. The Court emphasised that it is unacceptable for the President to create additional criteria which do not result from the Act. It added, however, that if the President concludes that experience and moral features do not guarantee the proper holding of the judicial office, he has not only the right, but an obligation to refuse to appoint a judge ${ }^{45}$. It was also indicated in the order that the obligation to present suitable motives for the refusal of the Head of State in terms of appointing a judge results from the principle of state of law, the legality principle, and arbitrage prohibition ${ }^{46}$.

In reference to the above-mentioned order of the Supreme Administrative Court in Brno, it should be noted, however, that the systemic position of the President of the Czech Republic, as well as his powers regarding the appointment of judges, are constructed differently to the norm provided for in the Constitution of the Republic of Poland. The Czech Constitution ${ }^{47}$ admittedly provided then for the fact that the President of the Republic is the Head of State, nevertheless, he was elected by the Parliament at a joint meeting of both chambers, which is a characteristic of the parliamentary-cabinet model (Article 54 section 1 and 2 of the Constitution of the Czech Republic). ${ }^{48}$ It should be emphasised, however, that the amendment to the Constitution ${ }^{49}$ in 2012 concerning the manner of electing the President of the Republic did not change the fact that the Czech SAC (NSS) still controls the decisions of the President of the Czech Republic. After 2013, when the President was elected in a general election, there was a case of a refusal to nominate university professors. Those involved filed complaints against this act in the first instance administrative court which ordered to nominate them. The President filed a complaint about the order in the SAC (NSS) in Brno, but he withdrew the complaint in cassation then, for fear of a decision that would be unfavourable for him. After the validation of the judgement, the President refused to grant professorships

45 P. Molek, Relacje między prezydentem a władzą sądowniczą w republice parlamentarnej, in: Sądownictwo administracyjne w Polsce i Czechach (wybrane zagadnienia omawiane w ramach polsko-czeskiej wspótpracy sędziów sądów administracyjnych), Warszawa 2018, p. 43.

46 A. Roztocil, Orzecznictwo dotyczące aktów prezydenta w zakresie powotywania i odwotywania sędziów oraz sędziów funkcyjnych, in: Sądownictwo administracyjne w..., p. 54.

47 Ustawa Konstytucyjna Czeskiej Rady Narodowej z dnia 16 grudnia 1992 r. Konstytucja Republiki Czeskiej (Sbírka Zákonů České Republiky of 1993, No. 1 of 28 December 1992 - text available at: biblioteka.sejm.gov.pl - Polish translation by M. Kruk Jarosz.

48 M. Kruk, O trybie wyboru Prezydenta Republiki Czeskiej, in: Ustroje, tradycje i porównania. Ksiega jubileuszowa dedykowana prof. dr hab. Marianowi Grzybowskiemu w siedemdziesiąt a rocznicę urodzin, eds. P. Mikula, A. Kulig, J. Karpa, G. Kuc, Warszawa 2015, p. 460.

49 Constitutional Act No. 71/2012 Sb. and Act No. 275/2012 Sb. on the Election of the President of the Republic and on Amending Certain Acts (zákon o volbě prezidenta republiky). 
again, and the persons involved filed complaints in the administrative court in Prague. The case has not reached its final conclusion so far, nevertheless, the judicial administrative cognition was decided in such cases ${ }^{50}$.

It should be noted that the President's competence in appointing judges was shaped differently in the Czech Republic. As opposed to the Polish constitutional model, the right to appoint judges in the Czech Republic does not constitute a presidential prerogative and was covered by the obligation to obtain a countersignature. Therefore, it does not constitute the absolute power of the Head of State. In accordance with Article 63 section 1 letter " $i$ " of the Czech Constitution, the President of the Republic nominates judges. However, pursuant to Article $63 \mathrm{sec}-$ tion 3 and 4 of this norm, the decisions of the President of the Republic issued on the basis of section 1 and 2 , thus, also concerning the appointment of judges, require the signature of the head of the government (Prime Minister) or the signature of another member of the government who has been authorised by the Prime Minister, for the validity of these decisions. It is assumed that the institution of a countersignature is a form of restriction on the President's systemic position, and thereby restriction of his power, by forcing, when it comes to some issues, including the case of nominating judges, co-operation of the President and the government. In turn, if a specified act of the Head of State was exempt from the obligation to obtain a countersignature, this means that it constitutes a presidential prerogative, the essence of which is the possibility for the President to adopt a given act, even against the will of other bodies of the state. ${ }^{51}$ In the Czech model, in practice, a list of candidates for judges is usually presented to the President of the Czech Republic twice a year. Because the appointment of judges was not excluded from the Prime Minister's or an authorised minister's countersignature, the list of the candidates is also sent to the government for acceptance. In the light of the case law of the Supreme Administrative Court in Brno and of the doctrine, it is assumed that the President may refuse to appoint a judge only in exceptional situations, and his act is subject to the control of the administrative court. ${ }^{52}$

\footnotetext{
$50 \quad$ P. Molek, Relacje między prezydentem..., p. 43.

51 L. Garlicki, Polskie prawo konstytucyjne, Warszawa 2012, p. 268.

52 M. Bobek, The Administration of Courts in the Czech Republic. In Search of Constitutional Balance, "European Public Law" 2010, No. 16, pp. 260-263.
} 


\section{Concluding remarks}

This paper presents a synthesis of the most important doctrinal and case-law standpoints with reference to the refusal of appointing a judge by the President. A number of issues, which I attempted to indicate and evaluate by myself, appear against this background.

In the sense of Article 179 of the Constitution of the Republic of Poland, judges are appointed by the President of the Republic of Poland, upon the NCJ's request, for an indefinite period of time. According to Article 144 section 2, in turn, the President's official acts require the signature of the Prime Minister, who is liable to the Sejm by signing the act, for their validity. The objection included in Article 144 section 3 of the Constitution of the Republic of Poland, pursuant to which the provision of section 2 does not concern acts enumerated in points 1-30. The appointment of judges is discussed in Article 144 section 3 point 17 of the Constitution. The President may thus issue an act on the appointment of a judge only upon request of the NCJ and it is not subject to the Prime Minister's countersignature.

Administrative courts consistently maintain that the President is not a body of the public administration in the sense of the Administrative Procedure Code in such a case. No administrative procedure in this regard is conducted in the Chancellery of the President, and the Head of State executes his constitutional competences (prerogatives), thus, there is no administrative-legal relationship either between him and the person who is interested in being appointed as a judge, or between him and the NCJ. In my opinion, these arguments are not entirely convincing. Such an interpretation of the President's act is admittedly supported by his high systemic position, however, the addressee of the President's decision, in which that person's subjective right to access to public service, in this case, the judicial service, should have a guarantee, within the rule of law, of the right to the judicial-administrative control of that act. The example of the Czech Republic indicates that disputes of this kind are a natural phenomenon of sparkling between individual segments of power, frequently claiming the right to remain in an area of absolute power, devoid of any control, including the judicial one. In my opion, such mechanisms should be gradually eliminated from relationships between citizens (candidates for judges) and the state authorities. Covering such acts of the Head of State by the judicial administrative cognition in the future could successfully find its rational justification within other acts and administrative activities regarding the rights and obligations resulting from the law (Article $3 \S 2$ point. 4 of the L.P.A.C.). This is because it is assumed that this norm may be a barrier against 
avoiding the judicial administrative control by the state authorities. ${ }^{53}$ In the literature and in some way in the case law of administrative courts, there is a concept, according to which when a substantive norm requires an authoritative concretisation, and legal regulations do not shape a substantive relationship on the basis of another form, it is assumed that an administrative case was settled in the form of a decision. This regards situations when a norm of the substantive law will be the basis for the derivation of the right or obligation of an individual, thus, when the individual's subjective right comes into play, as in this case. I think that a similar could be successfully used in the judicial administrative case law in reference to the decision of the President of the Republic of Poland regarding the refusal to appoint judges. This would, however, require a change of the perennial, consistent line of the case law of the administrative courts. ${ }^{54}$

In my opinion, questioning the decisive role of the President in the nomination procedure is unfounded. The fact that he has the right to make a substantive evaluation of the application results directly from the Act on the NCJ, in the light of which the President may file an application for the Council to reconsider the case, pointing out the impediments for the appointment of a judge. It is difficult to accept the fact of binding the President of the Republic of Poland by the NCJ's application submitted after the case has been reconsidered, and the fact of reducing his role to a purely ceremonial approval of that authority's application. Any potential refusal of appointing a judge should, however, be exceptional and justified on the grounds of the Constitution. The President should indicate the motives for his decision, which would make this act, with all of its arbitrariness, more transparent. This is crucial not only from the point of view of the person interested in being appointed as a judge, but it also has an important social and personal dimension. In its current form, it can violate the personal rights of such an individual. In the light of the current constitutional norm, it seems that the President, in fact, is under no such obligation. A change of a constitutional custom in this regard could, however, be an expression of good constitutional practice.

53 M. Kowalski, Prawo do sq̨du administracyjnego. Standard międzynarodowy $i$ konstytucyjny oraz jego realizacja, Warszawa 2019, p. 452.

54 B. Adamiak, Prawo do procesu w świetle regulacji prawa procesowego administracyjnego, in: System prawa administracyjnego, Vol. 9, Prawo procesowe administracyjne, eds. R. Hauser, Z. Niewiadomski, A. Wróbel, Warszawa 2010, pp. 93-94. 


\section{References}

Adamiak B., Prawo do procesu w świetle regulacji prawa procesowego administracyjnego, in: System prawa administracyjnego, tom 9, Prawo procesowe administracyjne, eds. R. Hauser, Z. Niewiadomski, A. Wróbel, Warszawa 2010.

Banaszak B., Konstytucja Rzeczypospolitej Polskiej. Komentarz, Warszawa 2009.

Bobek M., The Administration of Courts in the Czech Republic, "In Search of Constitutional Balance, European Public Law" 2010, nr 16.

Brzozowski W., Niezależność konstytucyjnego organu państwa i jej ochrona, Warszawa 2016.

Ciapała J., Charakter kompetencji Prezydenta RP. Uwagi w kontekście kompetencji w zakresie powotywania sędziów, „Przegląd Sejmowy” 2008, nr 4(87).

Ereciński T., Gudowski J., Iwulski J., Prawo o ustroju sądów powszechnych, Ustawa o Krajowej Radzie Sądownictwa. Komentarz, ed. J. Gudowski, Warszawa 2010.

Garlicki L., Komentarz do art. 179 Konstytucji RP, Tom IV, Warszawa 2005.

Garlicki L., Niezależność sądownictwa - powoływanie sędziów - nadrzędność konstytucji (kilka uwag nad ewolucja orzecznictwa Sąu Najwyższego w Indiach), in: Aktualne problemy konstytucji. Księga jubileuszowa z okazji 40-lecia pracy naukowej Profesora Bogustawa Banaszaka, eds. H. Babiuch, P. Kapusta, J. Michalska, Legnica 2017.

Garlicki L., Polskie prawo konstytucyjne, Warszawa 2012.

Hauser R., Stosunek administracyjnoprawny, in: Instytucje prawa administracyjnego, eds. R. Hauser, Z. Niewiadomski, A. Wróbel, C.H. Beck, Warszawa 2015.

Kowalski M., Nadużycie prawa do informacji publicznej, ZNSA 2016, nr 2(65).

Kowalski M., Prawo do sadu administracyjnego. Standard międzynarodowy i konstytucyjny oraz jego realizacja, Warszawa 2019.

Kowalski M., Terminy w postępowaniu administracyjnymi i sądowoadministracyjnym, Wroclaw 2013.

Kuczyński T., Z problematyki postępowania w sprawie powołania sędziego sądu administracyjnego, in: W stużbie dobru wspólnemu. Księga jubileuszowa dedykowana Profesorowi Januszowi Trzcińskiemu, eds. R. Balicki, M. Masternak-Kubiak, Warszawa 2012.

Kruk M., O trybie wyboru Prezydenta Republiki Czeskiej, in: Ustroje, tradycje i porównania. Ksiega jubileuszowa dedykowana prof. dr hab. Marianowi Grzybowskiemu w siedemdziesiąt a rocznicę urodzin, eds. P. Mikula, A. Kulig, J. Karpa, G. Kuc, Warszawa 2015.

Łabno A., Krajowa Rada Sądownictwa. Pozycja ustrojowa i możliwości reformy. Wybrane zagadnienia, in: Aktualne problemy konstytucji. Ksiegga jubileuszowa z okazji 40-lecia pracy naukowej Profesora Bogusława Banaszaka, eds. H. Babiuch, P. Kapusta, J. Michalska, Legnica 2017.

Molek P., Relacje między prezydentem, a władza sądownicza w republice parlamentarnej, in: Sądownictwo administracyjne w Polsce i Czechach (wybrane zagadnienia omawiane w ramach polsko-czeskiej wspótpracy sędziów sądów administracyjnych), Warszawa 2018.

Niewiadomski Z., Pojęcie administracji publicznej, in: Instytucje prawa administracyjnego, eds. R. Hauser, Z. Niewiadomski, A. Wróbel, C.H. Beck, Warszawa 2015. 
Piotrowski R., Sędziowie a władza wykonawcza. Wybrane problemy konstytucyjne, "Studia Iuridica" 2008, t. XLVIII.

Roztocil A., Orzecznictwo dotyczace aktów prezydenta w zakresie powolywania i odwotywania sędziów oraz sędziów funkcyjnych, in: Sądownictwo administracyjne w Polsce i Czechach (wybrane zagadnienia omawiane w ramach polsko-czeskiej wspótpracy sędziów sądów administracyjnych), Warszawa 2018.

Sarnecki P., Nota 11 Komentarza do art. 144 Konstytucji RP, Tom IV, Warszawa 2005.

Sokolewicz W., Konstytucyjna regulacja władzy sąowniczej, in: Konstytucja, ustrój, system finansowy państwa. Księga pamiątkowa ku czci prof. Natalii Gail, Warszawa 1999.

Sułkowski J., Dokumenty - wyrok Najwyższego Sąu Administracyjnego w Brnie z dnia 27 kwietnia 2006 r., sygn. akt 4 Aps 3/2005 dotyczacy kognicji sądowoadministracyjnej odnośnie do kontroli legalności aktów Prezydenta Republiki Czeskiej w przedmiocie odmowy powołania na stanowisko sędziowskie, „Przegląd Sejmowy” 2008, nr 4.

Sułkowski J., Uprawnienia Prezydenta RP do powotywania sędziów, „Przegląd Sejmowy” 2008, nr 4.

Szmyt A., Wątpliwości wokót reform wymiaru sprawiedliwości, in: Ratio est anima legis. Księga Jubileuszowa ku czci Profesora Janusza Trzcińskiego, Warszawa 2007.

Szwast M., Prawo do odpowiedniego ukształtowania ustroju i pozycji organów wymiaru sprawiedliwości, rozprawa doktorska obroniona w 2017 r. na WPiA UW, niepublikowana.

Ziółkowski M., Prerogatywa Prezydenta RP do powotywania sędziów (uwagi o art. 144 ust. 3 pkt 17 i art. 179 Konstytucji), „Przegląd Sejmowy” 2013, nr 1. 